\title{
Association between Dichlorodiphenyldichloroethylene in the Serum and Adipose Tissue with Type 2 Diabetes: A Systematic Review and Meta-Analysis
}

\author{
Yadolah Fakhri ${ }^{1}$, Amir Sheikhmohammadi ${ }^{2}$, Abotaleb Bay ${ }^{3}$, Yahya Zandsalimi ${ }^{4}$, Bigard Moradi ${ }^{5}$, \\ Moayed Avazpour ${ }^{6}$, Milad Moloudizargari ${ }^{7}$, Milad Adel ${ }^{8}$, Sayed Mohsen Mohseni ${ }^{9}$ \& Hassan Keramati ${ }^{10}$ \\ ${ }^{1}$ Food and Cosmetic Health Research Center, Hormozgan University of Medical Sciences, Bandar Abbas, Iran \\ ${ }^{2}$ Studends Research Office, Department of Environmental Health Engineering, School of Public Health, Shahid \\ Beheshti University of Medical sciences, Tehran, Iran \\ ${ }^{3}$ Environmental Health Research Center, Golstan University of Medical Sciences, Golstan, Iran \\ ${ }^{4}$ Environmental Health Research Center, Kurdistan University of Medical Sciences, Sanandaj, Iran \\ ${ }^{5}$ Department of Health Public, Kermanshah University of Medical Sciences, Kermanshah, Iran \\ ${ }^{6}$ Department of Environmental Health Engineering, School of Public Health, Ilam University of Medical \\ Sciences, Ilam, Iran \\ ${ }^{7}$ Young researchers and elite club, Urmia branch, Islamic azad university, Urmia, Iran \\ ${ }^{8}$ Department of Aquatic Animal Health and Diseases, Iranian Fisheries Science Research, Institute (IFSRI), \\ Agricultural Research Education and Extension Organization (AREEO), Tehran, Iran \\ ${ }^{9}$ Department of Environmental Health Engineering, School of Public Health, Qom University of Medical \\ Sciences, Qom, Iran \\ ${ }^{10}$ Semnan University of Medical Sciences, Semnan, Iran \\ Correspondence: Hassan Keramati, Department of Environmental Health Engineering, School of Public Health, \\ Semnan University of Medical Sciences, Semnan, Iran. Tel: 98-91-2849-7093. E-mail: Hkramatee@gmail.com
}

Received: February 4, 2016 Accepted: April 30, 2016 Online Published: June 30, 2016

doi:10.5539/gjhs.v9n2p43 URL: http://dx.doi.org/10.5539/gjhs.v9n2p43

\begin{abstract}
The number of diabetics is growing every day. In addition to the main risk factors of type 2 diabetes (obesity, age and etc.) other environmental risk factors such as persistent organic pollutants are also considered. Dichlorodiphenyldichloroethylene is one of the persistent organic pollutants which are produced by the pesticide DDT metabolized and its effects of type 2 diabetes are taken into consideration of many investigators. Inconsistency in the results caused to try to achieve a detailed assessment of the effect of dichlorodiphenyldichloroethylene on type 2 diabetes by systematic review and meta-analysis. In this review study after a systematic review, finally 6 prospective and 7 cross-sectional studies were obtained. After approving the heterogeneity of the studies based on random effect model, it was calculate the mean of odds ratio. Meta-analysis of the pooled random effects of Dichlorodiphenyldichloroethylene was done with type 2 diabetes in prospective and cross-sectional studies. In prospective studies, the highest and lowest odds ratio was 6.1 (95\%CI: 1.36-27.27) and 1.01 (95\%CI: 0.59-1.70) and cross-sectional studies was 5.5 (95\%CI: 1.2-25.10) and 0.61 (95\%CI: $0.32-1.15$ ), respectively. In the all studies (sum of prospective and cross-sectional), in the random effect model odds ratio was $1.52(95 \% \mathrm{CI}: 1.26-1.84)$ and heterogeneity was $52.1 \%$ ( $\left.\rho_{\text {heterogeneity }}=0.009\right)$. Increasing concentration of Dichlorodiphenyldichloroethylene in the serum and adipose tissue increased the risk of type 2 diabetes significantly $(\mathrm{P}<0.001)$. The results of this review study support the role of dichlorodiphenyldichloroethylene as an environmental risk factor for type 2 diabetes.
\end{abstract}

Keywords: type 2 diabetes, dichlorodiphenyldichloroethylene, serum tissue, adipose tissue 


\section{Introduction}

Diabetes is becoming an important public health challenge (DeFronzo, Ferrannini, Zimmet, \& Alberti, 2015; Hu, 2011). From 1980 to 2004, the population have diabetes in the United States has reached from 5.8 million to 14.7 million and only in 2004; 1.4 million new diabetics were recognized (18-79 years old) (Surveillance for dental caries, 2005). High blood sugar due to insulin resistance and beta cell dysfunctions cause a metabolic disease named Type 2 Diabetes (T2D) (Kahn, 2003). The prevalence of T2D was 2.8\% in 2000 and is forecast to reach $4.4 \%$ by 2030 (Wild, Roglic, Green, Sicree, \& King, 2004). The World Health Organization (WHO) has predicted that diabetes would be the seventh leading cause of death in 2030 that more than $80 \%$ of them live in the countries with low to moderate income (IDF, 2011). Also, the International Diabetes Federation (IDF) has reported that in 2013, 382 million human $(8.3 \%)$ of the world's population suffered from diabetes that 175 million of them have not been diagnosed and has predicted that almost 592 million human $(10.1 \%)$ will be affected to this disease by the year 2035 (IDF, 2011). This increasing process is assigned to the environmental and genetic factors (Das, 2010; Cornelis, Zaitlen, Hu, Kraft, \& Price, 2015). Diabetes risk factors include low motility, obesity, genetics, race, age, hypertension, high triglycerides and low high density lipoproteins (HDL) (Katzmarzyk, 2008; Group, 2013). Genetic factors have allocated only 6\% of the share of T2D development (Eichler, Flint, Gibson, Kong, Leal, 2010) and the role of environmental factors in causing the disease are known (Patel, Bhattacharya, \& Butte, 2010). Environmental factors are such as arsenic, persistent organic pollutants (POPs), Bisphenol A, Phthalates and smoking (Gray, Shaw, Gagne, \& Chan, 2013; Lee, Song, Steffes, \& Toscano, 2006; Thayer, Heindel, Bucher, \& Gallo, 2012; Taylor, Novak, Anderson, Birnbaum, \& Blystone, 2013). Persistent organic Pollutants are included: Organo-chlorinated compounds (tetrachlorodibenzopdioxin (TCDD or dioxin), polychlorinated dibenzofurans (PCDFs), polychlorinated dibenzop-non TCDD (PCDDs), dioxins, dichlorodiphenyldichloroethane (DDD) and (PCBs)), Bromine compounds [polybrominated diphenyl ethers (PBDEs), polybrominated biphenyls (PBBs)], Perfluorescent compounds [perfluorooctane sulfonate (PFOS)], perfluorooctanoic acid (PFOA), perfluorohexane sulfonate and perflorononanoic acid (Taylor et al., 2013). Dichlorodiphenyldichloroethylene (p,p'-DDE, CAS\#82413-20-5) is one of the products that are metabolized and is created by hydrogen reduction from DDT. DDT has been widely used in homes and agriculture as pesticides from 1940 to 1980 (Arrebola, Fernández, Olea, Ramos, \& Martin-Olmedo, 2013). This pesticide is still used in developing countries (Wendo, 2004). Although it is a long time that the use of organo-chlorinated pesticide is banned or limited, but due to the high resistance of the metabolized products of these compounds such as p,p'-DDE, they are still available in different environments and cause the adverse effects of health. Unlike p,p'-DDT that fast degradable in the environment, p,p'-DDE is resistant in environment and easily inter and accumulate in the adipose tissue (Dorea, Cruz-Granja, Lacayo-Romero and Cuadra-Leal, 2001). The United States Environmental Protection Agency (EPA) has classified p,p'-DDE in 2B (Probable Human Carcinogen) (U.S.EPA, 1994) and also it is observed that exposure to p,p'-DDE causes some allergies such as interleukin-4 through changes in T cells in addition to diabetes (Bilrha, Roy, Moreau, Belles-Isles, \& Dewailly, 2003; Daniel, Huber, Bauer, Suesal, \& Conradt, 2002). p,p'-DDE is in sediments and food chain (Sunyer, Torrent, Muñoz-Ortiz, Ribas-Fitó, \& Carrizo, 2005; Wallin, Di Giuseppe, Orsini, Åkesson, \& Forouhi, 2015; Turusov, Rakitsky, \& Tomatis, 2002). The main source of human exposure to p,p'-DDE is through eating food, particularly fish. Several cross-sectional studies have disclosed the association of POPs with T2D (Lee et al., 2006 ; Taylor et al., 2013 ; Airaksinen, Rantakokko, Eriksson, Blomstedt, \& Kajantie, 2011; Mostafalou, 2016). Some limited prospective studies have also shown that POPs increased the risk of T2D (Arrebola, Pumarega, Gasull, Fernandez, \& Martin-Olmedo, 2013; Rignell-Hydbom, Lidfeldt, Kiviranta, Rantakokko, \& Samsioe, 2009; Turyk, Anderson, Knobeloch, Imm, \& Persky, 2009), but the association between p,p'-DDE and T2D has not been specifically studied. In certain studies, p,p'-DDE is related to T2D (Airaksinen et al., 2011; Hectors, Vanparys, Van Der Ven, Martens, \& Jorens, 2011) and there is not a significant association in certain studies (Wang, Tsai, Yang, \& Guo, 2008). Therefore, we tried to perform systematic review and meta-analysis to obtain an accurate evaluation of the association between p,p'-DDE in the serum and adipose tissue with T2D.

\section{Materials and Methods}

\subsection{Search and Selection of Studies}

A list of titles and abstracts of all articles available in databases such as Pubmed, Scopus, Ovid, Embase and ISI Web of Science from 2015.10.03 to 2015.10.19 was prepared at first by researchers in order to determine and select the related titles to be evaluated independently. Then, the papers related to blinding method of initial evaluation were entered to the process independently. The main inclusion criterion of several studies to this research is a point to the estimation of p,p'-DDE concentration in different age groups, men and women and different concentrations and its association between the T2D. The studies that were not a part of initial researches 
or in an unrelated field with the title of T2D and review studies were excluded from this study. In the second step using a check list of STROBE (Strengthening the Reporting of observational studies in Epidemiology) which is a standard check list, studies were evaluated. This check list was included 43 various parts and evaluates various aspects of methodology such as measuring methods, measuring variables, statistical analysis and aims of study. In this check list, the minimum and maximum obtained scores were considered as 40 and 45 , respectively (Von Elm, Altman, Egger, Pocock, \& Gøtzsche, 2007). Finally, the superior studies which had obtained the minimum score of 40 were entered into the research and its related data were extracted for meta-analysis. At the end, the prospective (Cohort) and cross-sectional studies which had studied their association between the concentrations of p,p'-DDE with T2D, were evaluated accurately. There were no restrictions on the language selection because of all the main studies were published English language. Also used to the Boolean term "AND" for combination of the keywords.

The keywords which were used for searching, generally includes the following:

T2D (T2D) and dichlorophenyldichlorodiene (p,p-DDE), phthalates, insulin resistance and T2D, Bisphenol a and diabetes, men and women, cross-sectional and prospective studies, serum, adult, aged, body burden, high density lipoprotein, low density lipoprotein and diabetes, diabetes mellitus and dichlorophenyldichlorodiene, adipose tissue and dichlorophenyldichlorodiene, chemically induced, female and male, health surveys, humans, middle aged, digestive, polychlorinated biphenyls, toxicity, prevalence and dichlorophenyldichlorodiene, diabetes, epidemiology, pops cholesterol, health survey, prevalent and dichlorophenyldichlorodiene, triacylglycerol, disease association, environmental exposure, human, prevalence, priority journal, questionnaire cholesterol, glucose and dichlorophenyldichlorodiene, lipid, T cell, pesticide and DDE, interleukin-4, DDT, DDT and dichlorophenyldichlorodiene, accumulate, pesticides, beta-cell function, international diabetes federation, fish consumption T2D.

\subsection{Data Extraction}

According to the standard method for data extraction, three independent investigators extracted and shape of the table all data. Disagreements points about studies resolved by consensus between three investigators. Information extracted included first author, publication year, study design, concentration of p,p-DDD in serum and adipose tissue, sample size, odds ratio (OR), confidence interval, $P$ value and population study.

\subsection{Data Analysis and Synthesis}

All statistical analysis was performed by Comprehensive Meta-Analysis V.2.2.064 software. Heterogeneity index using the heterogeneity test between the studies was determined by using heterogeneity test. After proving the heterogeneity of studies based on the effect random model, mean to odds ratio was calculated. Meta-analysis of pooled random effects p,p-DDE with T2D was done in the prospective and cross-sectional studies. To search about the heterogeneity of studies, several methods were proposed but one of the most common of them is drawing a funnel plot (Arlington, 2008). This plot used when the number of the evaluated studies is not less than 10 (Durand, Promotion, \& Management, 2008). The forest plot was used in the random model for evaluating the significance of serum p,p'-DDE and T2D in each study. Since, the number of studies in review studies are low, the significance level in heterogeneity test is $\mathrm{p}$ value $<0.001$ (Arlington, 2008).

\section{Results}

From 455 studies (Ovid ( $\mathrm{n}=17)$, Scopus ( $\mathrm{n}=73)$, Embase ( $\mathrm{n}=9$ ), ISI web of science $(\mathrm{n}=196)$ and Pubmed studies $(\mathrm{n}=160)$ excluded 374 studies were duplicated records and remained 81 ones were reviewed abstract. Then, excluded Reviews, editorials, commentaries, and case reports $(\mathrm{n}=24)$ animal studies and human in vitro or in vivo studies $(n=19)$ irrelevant exposures or outcomes $(n=22)$. From 16 studies remained that excluded from review; outcome was type 1 diabetes $(\mathrm{n}=2)$ and outcome was diabetes mortality $(\mathrm{n}=1)$. Finally, 6 Prospective and 7 cross-sectional studies remained for evaluation (Figure 1). 


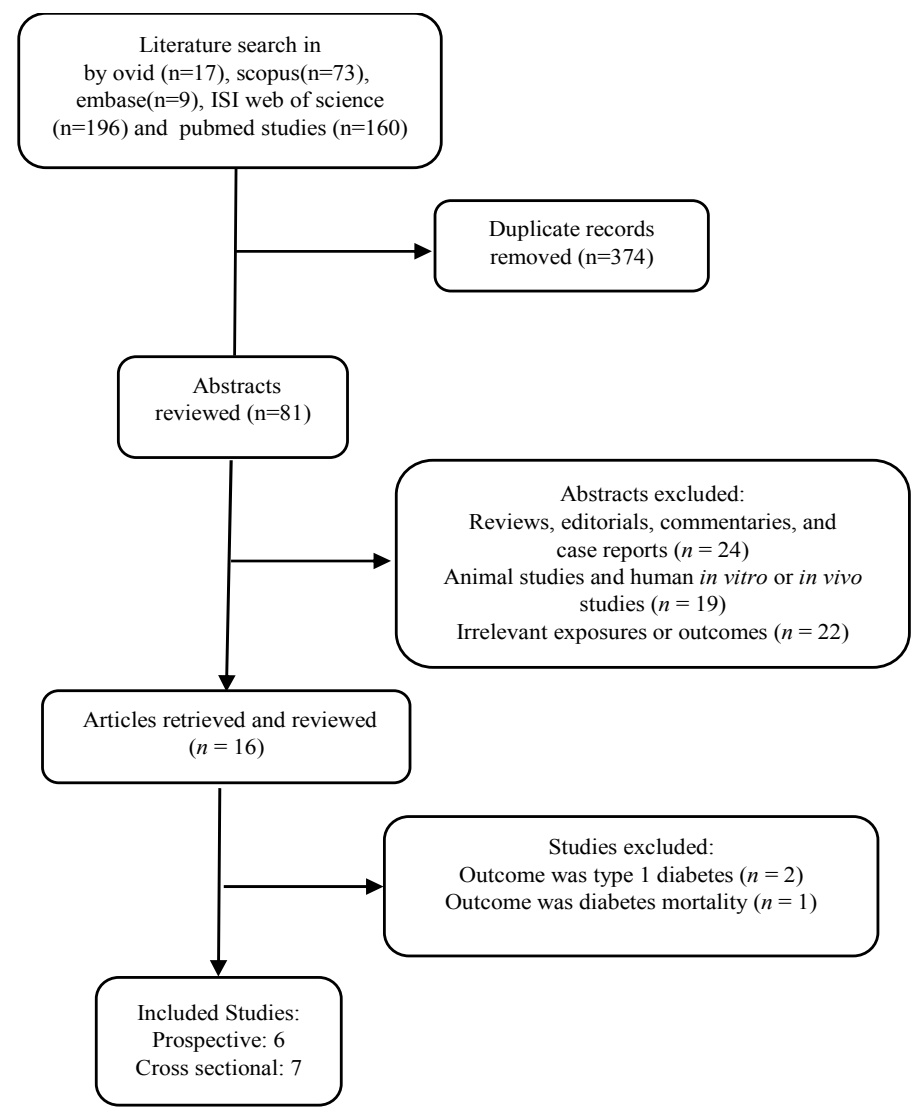

Figure 1. The results of research in databases of Ovid, Scopus, Embase, ISI Web of Science, Pubmed using the research strategy

In prospective studies, the maximum and minimum odds ratio was for Philibert et al. and Wu et al. (BCS) studies and in cross-sectional studies was for Rignell-Hydbom et al. (>7 years) and Silverstone et al. (men), respectively.

Mean of odds ratio and heterogeneity was for the all studies $\mathrm{OR}=1.64 ; 95 \% \mathrm{CI}(1.22-2.20) ; \mathrm{I}^{2}=52.1 \%$; $\left.\rho_{\text {heterogeneity }} 0.009\right)$. Mean of odds ratio for the prospective studies $\left(\mathrm{OR}=1.64 ; 95 \% \mathrm{CI}(1.22-2.20) ; \mathrm{I}^{2}=46.1 \%\right.$; $\rho_{\text {heterogeneity }=0.063)}$ was less than cross-sectional studies $\left(\mathrm{OR}=1.47 ; 95 \% \mathrm{CI} \quad(1.13-1.90) ; \mathrm{I}^{2}=47.2 \%\right.$; $\rho_{\text {heterogeneity }}=0.022$ ), respectively (Table 1$)$.

Table 1. Characteristics of studies included in the systemic review and meta-analysis

\begin{tabular}{|c|c|c|c|c|}
\hline Type of study & First author & Study population & Date & OR, $(95 \% \mathrm{CI})$ \\
\hline \multirow{8}{*}{ 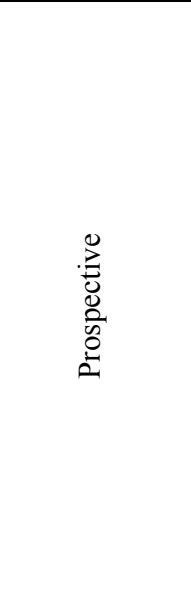 } & Larebeke et al. (Diabetes) & & & $1.67(1.25-2.24)$ \\
\hline & $\begin{array}{l}\text { Larebeke et al. (Diabetes or related } \\
\text { condition) }\end{array}$ & 775 adults men aged $50-65$ years & 2015 & $1.42(1.15-1.75)$ \\
\hline & Turyk et al. (2.3-5.3 ng/g lipid) & \multirow{2}{*}{515 Fish consumers } & \multirow{2}{*}{2009} & $5.50(1.2-25.1)$ \\
\hline & Turyk et al. (5.4-49.2 ng/g lipid) & & & $7.10(1.6-31.9)$ \\
\hline & Wu et al. (NHL) & \multirow{2}{*}{$\begin{array}{l}1095 \text { women who were free of } \\
\text { diabetes at blood draw in } \\
1989-1990\end{array}$} & \multirow[b]{2}{*}{2012} & $1.08(0.36-3.22)$ \\
\hline & Wu et al. (BCS) & & & $1.01(0.59-1.69)$ \\
\hline & Turyk et a & $\begin{array}{l}287 \text { participants who } \\
\text { did not have diagnosed diabetes } \\
\text { and did not use thyroid and } \\
\text { steroid hormone medications at } \\
\text { the } 2004-2005\end{array}$ & 2015 & $2.08(1.01-4.29)$ \\
\hline & Philibert et al. & 101 participants reported diabetes & 2009 & $6.11(1.37-27.3)$ \\
\hline
\end{tabular}




\begin{tabular}{|c|c|c|c|c|}
\hline & & (fish consumers) & & \\
\hline \multirow{16}{*}{$\begin{array}{l} \\
\\
\\
\bar{\Xi} \\
.0 \\
0 \\
0 \\
0 \\
0 \\
0 \\
0 \\
0\end{array}$} & Airaksinen et al. & 1988 Participants in the Helsinki & 2011 & $0.88(0.18-4.35)$ \\
\hline & $\begin{array}{l}\text { Silverstone et al. } \\
\text { (men) }\end{array}$ & $\begin{array}{l}774 \text { Anniston Community, adult }> \\
18 \text { years }\end{array}$ & 2012 & $0.61(0.32-1.15)$ \\
\hline & Silverstone et al. (women) & & & $1.42(1.03-1.95)$ \\
\hline & Gasull et al. (433.75-910.90 ng/g lipid) & 886 Catalan Health Interview & 2012 & $0.8(0.4-1.7)$ \\
\hline & Gasull et al. ( $>910.90 \quad \mathrm{ng} / \mathrm{g}$ lipid) & Survey in Catalonia & 2012 & $0.9(0.4-1.8)$ \\
\hline & Arrebola et al. (127.33-266.91 ng/g lipid) & 286 dults from Southorn Snoin & 2012 & $1.66(0.53-5.18)$ \\
\hline & Arrebola et al. (>266.91 ng/g lipid) & 380 aduits irom soutnem spain & 2013 & $2.93(1.01-8.47)$ \\
\hline & Rignell-Hydbom et al. (<1years) & & & $0.90(0.57-1.4)$ \\
\hline & Rignell-Hydbom et al. (>3 years) & 371women, age 50-59 years, & 2000 & $1.50(0.8-2.8)$ \\
\hline & Rignell-Hydbom et al. (>5 years) & from the Southern part of Sweden & 2007 & $2.50(0.97-6.4)$ \\
\hline & Rignell-Hydbom et al. (>7 years) & & & $5.50(1.2-25)$ \\
\hline & Codru et al. (Medium tertile) & 352 adults, $\geq 30$ years of age & & $1.60(0.5-4.8)$ \\
\hline & Codru et al. (Highest tertile) & $\begin{array}{l}\text { [adult Native-American } \\
\text { (Mohawk) population] }\end{array}$ & 2007 & $2.40(0.7-8.3)$ \\
\hline & Cox et al. (39.10-58.60 ng/g lipid) & 1303 Mexican Americans 20-74 & & $2.43(1-5.7)$ \\
\hline & Cox et al. (>58.6 ng/g lipid) & $\begin{array}{l}\text { years of age from the Hispanic } \\
\text { Health }\end{array}$ & 2007 & $2.63(1.2-5.8)$ \\
\hline & Ukropec et al. & $\begin{array}{l}\text { Participants A total of } 2,047 \\
\text { individuals }(835 \text { men, } 1212 \\
\text { women; age range } 21-75 \text { years }\end{array}$ & 2010 & $1.86(1.17-2.95)$ \\
\hline
\end{tabular}

\section{Discussion}

Meta-analysis of data showed that p,p-DDE in serum and adipose tissue was significant positive association between the T2D.

\subsection{Meta-Analysis}

In $\mathrm{Wu}$ et al. study is as $\mathrm{I}^{2}=36.8 \%$ ( $\rho_{\text {heterogeneity }}=0.161$ ) although heterogeneity in Wu et al. study has a less compared to our study, but this heterogeneity was not significant (Wu et al., 2012). Since we try to investigate more and newer studies in our research, it was expected to have differences in our results compared to other review articles. Overall heterogeneity was $\left(\mathrm{I}^{2}=52 \%\right.$, $\left.\rho_{\text {heterogeneit: }} 0.009\right)$ in the range of $30-60 \%$ hence was moderate class heterogeneity (Higgins and Green, 2008). Since in most review studies, the number of evaluated studies was low; so to compensate the low power, significance level for odds ratio and relative risk of $\mathrm{p}$ value $<0.001$ are considered (Schwarzer, Carpenter, \& Rücker, 2015). Although against the cross-sectional studies, $\mathrm{I}^{2}$ was not significant in prospective studies, but generally it can be said that the evaluated studies have a significant and moderate heterogeneity. 


\begin{tabular}{|c|c|}
\hline \multicolumn{2}{|c|}{$\underline{\text { Study name }}$} \\
\hline Larebeke & (Diabetes) \\
\hline Larebeke & (Diabetes or related condition) \\
\hline Airaksinen & \\
\hline Silverstone & e (Male) \\
\hline Silverstone & (Female) \\
\hline Arrebola & $(127.33-266.91 \mathrm{ng} / \mathrm{g})$ \\
\hline Arrebola & $(>266.91 \mathrm{ng} g)$ \\
\hline Turyk & $(2.3-5.3 \mathrm{ng} g)$ \\
\hline Turyk & $(5.4-49.2 \mathrm{ng} \mathrm{g})$ \\
\hline Rignell & $(<$ lyears $)$ \\
\hline Rignell & $(>3$ years $)$ \\
\hline Rignell & $(>5$ years $)$ \\
\hline Rignell & $(>7$ years) \\
\hline $\mathrm{Wu}$ & (NHL) \\
\hline $\mathrm{Wu}$ & (BCS) \\
\hline Codru & (Medium tertile) \\
\hline Codru & (Highest tertile) \\
\hline Cox & $(39.10-58.60 \mathrm{ng} \mathrm{g})$ \\
\hline Cox & $(>58.6 \mathrm{ng} / \mathrm{g})$ \\
\hline \multicolumn{2}{|l|}{ Turyk } \\
\hline \multicolumn{2}{|l|}{ Ukropec } \\
\hline \multicolumn{2}{|l|}{ Philibert } \\
\hline Gasull & $(433.75-910.90 \mathrm{ng} / \mathrm{g})$ \\
\hline Gasull & $(>910.90 \mathrm{ng} g)$ \\
\hline Random & \\
\hline
\end{tabular}

\begin{tabular}{|c|c|c|c|c|}
\hline \multicolumn{5}{|c|}{ Statistics for each study } \\
\hline $\begin{array}{l}\text { Odds } \\
\text { ratio }\end{array}$ & $\begin{array}{c}\text { Lower } \\
\text { limit }\end{array}$ & $\begin{array}{c}\text { Upper } \\
\text { limit }\end{array}$ & Z-Value & p-Value \\
\hline 670 & 1.248 & 2.235 & 3.447 & 0.001 \\
\hline 420 & 1.151 & 1.752 & 3.274 & 0.001 \\
\hline 0.880 & 0.179 & 4.326 & -0.157 & 0.875 \\
\hline 0.610 & 0.322 & 1.156 & -1.516 & 0.130 \\
\hline .420 & 1.032 & 1.954 & 2.153 & 0.031 \\
\hline 1.660 & 0.531 & 5.190 & 0.871 & 0.383 \\
\hline 2.930 & 1.012 & 8.485 & 1.982 & 0.048 \\
\hline 5.500 & 1.203 & 25.154 & 2.198 & 0.028 \\
\hline 7.100 & 1.590 & 31.703 & 2.567 & 0.010 \\
\hline 0.900 & 0.574 & 1.410 & -0.460 & 0.646 \\
\hline 1.500 & 0.802 & 2.806 & 1.269 & 0.205 \\
\hline 2.500 & 0.973 & 6.422 & 1.904 & 0.057 \\
\hline 5.500 & 1.205 & 25.104 & 2.201 & 0.028 \\
\hline 1.080 & 0.361 & 3.230 & 0.138 & 0.890 \\
\hline 1.010 & 0.597 & 1.709 & 0.037 & 0.970 \\
\hline 1.600 & 0.516 & 4.957 & 0.815 & 0.415 \\
\hline 2.400 & 0.697 & 8.264 & 1.388 & 0.165 \\
\hline 2.430 & 1.018 & 5.802 & 2.000 & 0.046 \\
\hline 2.630 & 1.196 & 5.782 & 2.406 & 0.016 \\
\hline 2.080 & 1.009 & 4.287 & 1.985 & 0.047 \\
\hline 1.860 & 1.171 & 2.953 & 2.630 & 0.009 \\
\hline 6.110 & 1.369 & 27.275 & 2.371 & 0.018 \\
\hline 0.800 & 0.388 & 1.649 & -0.605 & 0.545 \\
\hline 0.900 & 0.414 & 1.956 & -0.266 & 0.790 \\
\hline & 1.268 & 1.840 & 4.463 & 0.000 \\
\hline
\end{tabular}

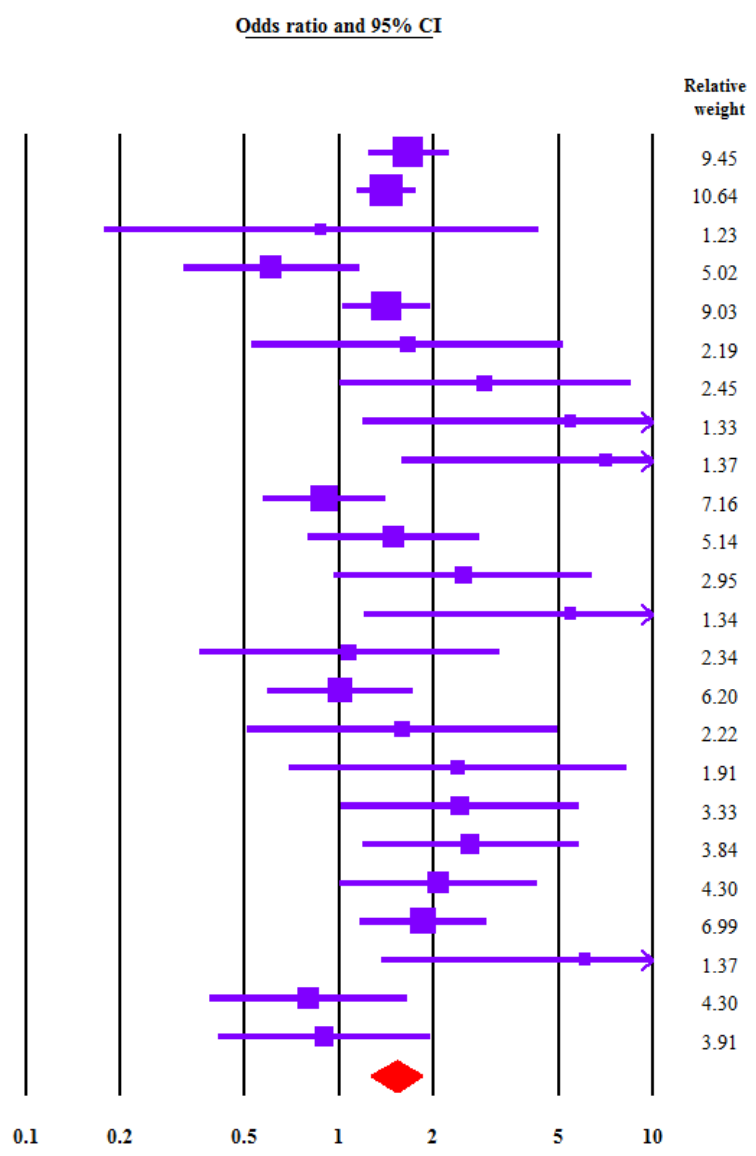

Figure 2. Forest plot of odds ratio of the T2D in the all studies

In general, the highest and lowest weight percentage was for Larebeke et al. study (diabetes or related condition) and Airaksinen et al. study, respectively (Figure 2). In prospective studies, the highest and lowest weight percentage was for Larebeke et al. study (diabetes or related condition) and Airaksinen et al. study, respectively (Figure 3) and in cross-sectional studies, Silverstone et al. (women) and Rignell-Hydbom ( $>7$ years) (Figure 4). Difference in weight percentage was induced by difference in confidence interval and the difference in confidence interval is due to the difference in type of study, number of population and concentration of p,p'-DDE (Egger, Davey-Smith, \& Altman, 2008). Due to the reverse funnel plot in both prospective and cross-sectional studies, publication bias has not been conducted in the all studies (Begg-Mazumdar test, $p$ value $=0.31$ ) (Rothstein, Sutton, \& Borenstein, 2006).

The studies showed that POPs concentration is decreasing in the environment (Rignell-Hydbom et al., 2009), but it should be noted that firstly, POPs increased the risk of diabetes in obese human by accumulation in adipose tissue (Lee et al., 2006) and secondly, many of old POPs such as PCBs or DDT and the new ones such as brominated flame-retardants, perfluorinated compounds, phthalates and bisphenol a have the nature of endocrine destruction creates a hormone imbalance (Rasier, Toppari, Parent, \& Bourguignon, 2006). 


\begin{tabular}{|c|c|c|c|c|c|c|}
\hline \multirow[t]{2}{*}{ Study nam } & & \multirow[b]{2}{*}{$\begin{array}{l}\text { Odds } \\
\text { ratio }\end{array}$} & \multicolumn{3}{|c|}{ Statistics for each study } & \multirow[b]{2}{*}{ p-Value } \\
\hline & & & $\begin{array}{c}\text { Lower } \\
\text { limit }\end{array}$ & $\begin{array}{c}\text { Upper } \\
\text { limit }\end{array}$ & Z-Value & \\
\hline Larebeke & (Diabetes) & 1.670 & 1.248 & 2.236 & 3.446 & 0.001 \\
\hline Larebeke & (Diabetes or related condition) & 1.420 & 1.151 & 1.752 & 3.274 & 0.001 \\
\hline Airaksinen & & 0.880 & 0.179 & 4.326 & -0.157 & 0.875 \\
\hline Turyk & $(2.3-5.3 \mathrm{ng} / \mathrm{g})$ & 5.500 & 1.203 & 25.154 & 2.198 & 0.028 \\
\hline Turyk & & 2.080 & 1.009 & 4.287 & 1.985 & 0.047 \\
\hline Turyk & $(5.4-49.2 \mathrm{ng} / \mathrm{g})$ & 7.100 & 1.590 & 31.703 & 2.567 & 0.010 \\
\hline $\mathrm{Wu}$ & (NHL) & 1.080 & 0.361 & 3.230 & 0.138 & 0.890 \\
\hline $\mathrm{Wu}$ & (BCS) & 1.010 & 0.597 & 1.709 & 0.037 & 0.970 \\
\hline Philibert & & 6.110 & 1.369 & 27.275 & 2.371 & 0.018 \\
\hline Random & & 1.646 & 1.229 & 2.205 & 3.339 & 0.001 \\
\hline
\end{tabular}

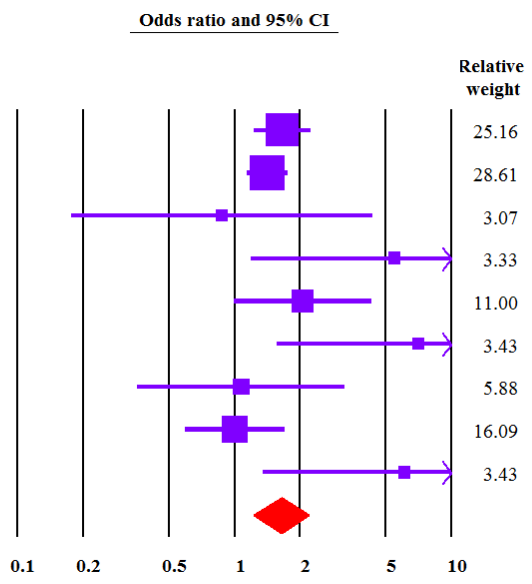

Figure 3. Forest plot of odds ratio of the T2D in prospective studies

\begin{tabular}{|c|c|c|c|c|c|c|}
\hline \multirow[t]{2}{*}{ Study name } & & \multicolumn{5}{|c|}{ Statistics for each study } \\
\hline & & $\begin{array}{l}\text { Odds } \\
\text { ratio }\end{array}$ & $\begin{array}{c}\text { Lower } \\
\text { limit }\end{array}$ & $\begin{array}{c}\text { Upper } \\
\text { limit }\end{array}$ & Z-Value & -Value \\
\hline Silverstone & (Male) & 0.610 & 0.322 & 1.156 & -1.515 & 0.130 \\
\hline Silverstone & (Female) & 1.420 & 1.032 & 1.954 & 2.154 & 0.031 \\
\hline Arrebola & $(127.33-266.91 \mathrm{ng} / \mathrm{g})$ & 1.660 & 0.531 & 5.190 & 0.871 & 0.383 \\
\hline Arrebola & $(>266.91 \mathrm{ng} / \mathrm{g})$ & 2.930 & 1.012 & 8.485 & 1.982 & 0.048 \\
\hline Rignell & (<1years) & 0.900 & 0.574 & 1.410 & -0.460 & 0.646 \\
\hline Rignell & $(>3$ years $)$ & 1.500 & 0.802 & 2.806 & 1.269 & 0.205 \\
\hline Rignell & ( $>5$ years) & 2.500 & 0.973 & 6.422 & 1.904 & 0.057 \\
\hline Rignell & (>7 years) & 5.500 & 1.205 & 25.104 & 2.201 & 0.028 \\
\hline Codru & (Medium tertile) & 1.600 & 0.516 & 4.957 & 0.815 & 0.415 \\
\hline Codru & (Highest tertile) & 2.400 & 0.697 & 8.264 & 1.388 & 0.165 \\
\hline Cox & $(39.10-58.60 \mathrm{ng} / \mathrm{g})$ & 2.430 & 1.018 & 5.802 & 2.000 & 0.046 \\
\hline Cox & $(>58.6 \mathrm{ng} / \mathrm{g})$ & 2.630 & 1.196 & 5.782 & 2.406 & 0.016 \\
\hline Ukropec & $(99-2436 \mathrm{ng} / \mathrm{g})$ & 1.860 & 1.171 & 2.953 & 2.630 & 0.009 \\
\hline Gasull & $(433.75-910.90 \mathrm{ng} / \mathrm{g})$ & 0.800 & 0.388 & 1.649 & -0.605 & 0.545 \\
\hline Gasull & $(>910.90 \mathrm{ng} / \mathrm{g})$ & 0.900 & 0.414 & 1.956 & -0.266 & 0.790 \\
\hline Random & & 1.473 & 1.139 & 1.905 & 2.947 & 0.003 \\
\hline
\end{tabular}

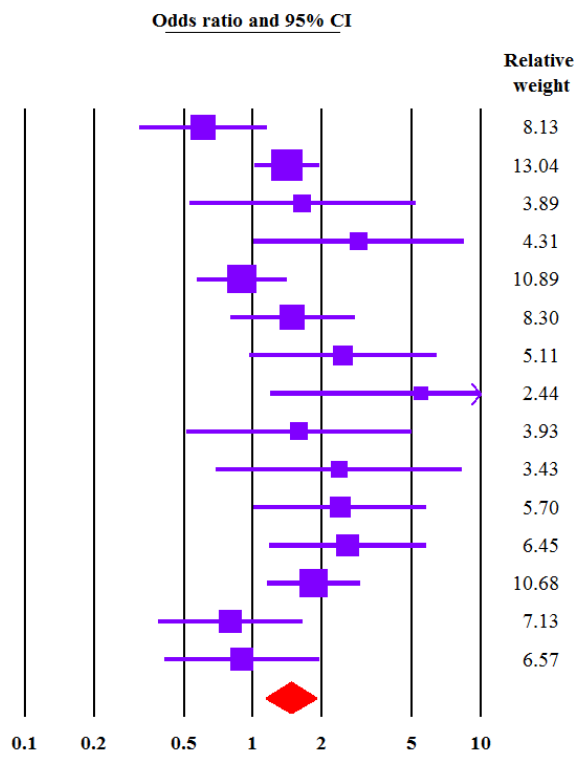

Figure 4. Forest plot of odds ratio of the T2D in cross-sectional studies

\subsection{Comparison Studies}

In Larebeke et al. study against women, the incidence of diabetes in men had a positive significant association between $p, p$ '-DDE concentration ( $p$ value $<0.001$ ). Although other POPs such as PCB-118 and HCB caused the increase in the incidence of T2D in men and women, but was no significant association between p,p'-DDE concentration and diabetes in women ( $p>0.52)$ (Van Larebeke et al., 2015). With increasing the concentration of p,p'-DDE in both studies, the risk of T2D was also increased.

In Turyk et al. (2015), the concentration of Ln-p,p-DD ( $2 \mathrm{ng} / \mathrm{g}$ lipid) was assessed by some diabetes biomarkers such as C-reactive protein (CRP), adiponectin and Gamma-glutamyl transpeptidase (GGT) in fish consumers. The results showed that risk of diabetes is significantly increased by increasing p,p'-DDE (Table 1). Geometric mean of $\ln$ p,p'-DDE concentration in men $(2.19 \mathrm{ng} / \mathrm{g}$ lipid) was more than women $(1.39 \mathrm{ng} / \mathrm{g}$ lipid), so higher increase in p,p'-DDE in men was due to more eating fish (11\% more) (Turyk et al., 2015). In a study by Azandjeme et al. in the area of Borgou at north of Benin among the residents in linen production area, the concentration of p,p'-DDE in men and women was 6.68 and $6.08 \mathrm{ln} \mathrm{ng} / \mathrm{g}$ lipid, respectively that women have less concentration than men similar to Turyk et al. study (Azandjeme, Delisle, Fayomi, Ayotte, \& Djrolo, 2014). 
Higher concentration of p,p'-DDE in men was due to more work of men and their more exposure compared to the women. On one hand, hard work causes more eating and will be followed by more absorption of p,p'-DDE.

In Turyk et al. study (2009) on fish consumers in great sport lake, it was determined that unlike PCB-118 and total PCBs, the concentration of p,p'-DDE had a positive significant association between T2D. The increase in concentration of p,p'-DDE cause an increase in the risk of diabetes (Table 1). As Turyk et al. (2015) and Azandjeme et al. studies in the range concentration of p,p'-DDE of 2.3-5.3 ng/g lipid, the risk of T2D in men $(\mathrm{OR}=6.8)$ was more than women $(\mathrm{OR}=3.9)$. In the present study, the concentration of $\mathrm{p}, \mathrm{p}$-DDE was much lower than other studies and there was a question that how low concentration of p,p'-DDE could create an almost equal risk of diabetes in other studies (Turyk et al., 2009).

$\mathrm{Wu}$ et al. study showed that the increase in concentration of $\mathrm{p}, \mathrm{p}$ '-DDE cannot significantly increase the risk of T2D in both groups of women with Non Hodgkin Lymphoma $(\mathrm{P}=0.86)$ and Breast Cancer Study $(\mathrm{P}=0.98)(\mathrm{Wu}$ et al., 2012) similar to Larebeke et al. study that HCB increased the risk of T2D significantly (Van Larebeke et al., 2015).

In RignellHydbom et al. study and after 7 years from the baseline examination, the increase in concentration p,p'-DDE [OR=5.5 (1.2-25)] and PCB-153 [OR=1.6 (0.6-4)] increased the risk of T2D (Rignell-Hydbom et al., 2009). It is while Wu et al. has cited wrong in his article that RignellHydbom et al. has said that only p,p'-DDE increases the risk of T2D (Wu et al., 2012). Serum concentrations after 7 years from the baseline examination were $5680 \pm 6160(\mathrm{pg} / \mathrm{ml})$ and $3890 \pm 3770(\mathrm{pg} / \mathrm{ml})$ in case and control groups respectively that had a higher difference between case and control compared to the last years (case more than control). Thus, it is expected that risk of T2D increases.

High OR in RignellHydbom et al. study compared to certain studies except fish consumers (Turyk et al., 2009; Philibert et al., 2009) due to the effect of other variables such as obesity, sex and etc.

In Gasull et al. study, concentration of p,p-DDE has no significant association between diabetes, but PCBs and HCB (like Larebeke et al. study and Wu et al. study) increased the risk of diabetes significantly. It is while the geometric mean concentration of p,p'-DDE was in the range of Turyk et al., but their results were different from each other (Gasull et al., 2012).

Codru et al. study showed that against the chemical material of Mirex, the increase in concentration of p,p'-DDE increased the risk of T2D significantly. Also, similar to Gasull et al. study, high HCB increased the risk of diabetes significantly. The concentration mean of $\ln$ p,p'-DDE $(6.26 \pm 6.23 \mathrm{ng} / \mathrm{g}$ lipid $)$ was more than Turyk et al. (2015) study and like this study, the risk of T2D was significantly increased (Codru et al., 2007). Langer et al. study showed that in the areas with high concentrations of PCB, p,p'-DDE and HCB, impaired fasting glucose was higher other areas (Langer, Kočan, Tajtaková, Petrík, \& Chovancová, 2007). Also Cox et al. study like Lee et al. study showed that concentration of p,p'-DDE in obese human is much more than slim human. On the other hand, concentration of p,p'-DDE has a significant association between T2D. The mean of concentration of p,p'-DDE (28.09 ng/g lipid) in this study was several times more than Codru et al., Turyk et al. (2015) and Azandjeme et al. (Cox, Niskar, Narayan, \& Marcus, 2007).

In Philibert et al. study, the mean of concentration of p,p'-DDE was $7.16 \mathrm{ng} / \mathrm{g}$ lipid in fish consumers which was more than the other studies and Turyk et al. (2009) (fish consumers). There was a significant and positive association between fish consuming and incidence of diabetes, so it has a low weight percentage in forest plot (Figure 3). Since the concentration of p,p'-DDE in this study is high, the risk of T2D in this study is also higher than other studies except Turyk et al. (2009). The odds ratio in Philibert et al. and Turyk et al. 2009 studies is more than other prospective and cross-sectional studies (Figure 3). One of the causes of this difference is fish consumption in the studied groups. Fish can store a lot of POPs in its tissue (Yu, Zhang, Huang, Li, \& Pang, 2012).

In Arrebola et al. study, the geometric mean of $\ln \mathrm{p}, \mathrm{p}$ '-DDE concentration in diabetics is $5.49 \mathrm{ng} / \mathrm{g}$ lipid. The risk of T2D increased by increasing p,p'-DDE concentration like other studies. It should be noted that in this study, only p,p'-DDE in adipose tissue had a significant association between T2D in the random and fixed models (Arrebola et al., 2013).

Airaksinen et al. study like RignellHydbom et al. study showed that the increase in p,p'-DDE and PCB-153 concentrations cause an in increase in the incidence of T2D, significantly (Airaksinen et al., 2011). Against the studies of Turyk et al. 2015 and Azandjeme et al. in Airaksinen et al. study, p,p'-DDE concentration had no significant difference between men $(600 \pm 18 \mathrm{ng} / \mathrm{g}$ lipid) and women $(610 \pm 16 \mathrm{ng} / \mathrm{g}$ lipid) ( $\mathrm{p}=0.64)$. Since eating is the main entrance way of POPs to the body (Fernández-González, Yebra-Pimentel, Martínez-Carballo, \& 
Simal-Gándara, 2015), so it can be said that type of food and its amount to use has been the same for men and women in this study. Against the studies of Turyke et al. (2009) and Azandjeme et al. in Silverstone et al. study, the risk of T2D due to PCBs and p,p'-DDE in women were more than men. The increased risk of T2D with p,p'-DDE in women and men were significant and insignificant, respectively. The higher risk of diabetes in women is due to more body fat and following that more accumulation of POPs in women's bodies, at first. Secondly, POPs is effective in estrogenic activity of women and following that glucose metabolism (Silverstone et al., 2012). But amount of exposure has the basic role in the increase concentration of p,p'-DDE, as some studies showed that concentration of p,p'-DDE in men has been more than women.

POPs induce diabetes through different mechanisms. The most important of these mechanisms include altered gene transcription, lipid metabolism, insulin production, changes in the insulin signaling pathway (Marchand, Tomkiewicz, Marchandeau, Boitier, \& Barouki, 2005) and altered glucose transport (Tonack, Kind, Thompson, Wobus, \& Fischer, 2007). It should be noted that each above mentioned mechanisms can be done in men and women. Ukropec et al. study showed that the increase in PCBs and p,p'-DDE increased the risk of T2D significantly. The range of ln p,p'-DDE for p,p'-DDE was 6.08-8.76 ng/g lipid. Against the studies of Langer et al., Gasull et al., Codru et al., Wu et al. and Larebeke, in Ukropec et al. study no significant association between HCB concentration and T2D was not observed. This difference in the results due to the lack of consideration of variables such as age, sex and BMI or low concentration of HCB (Ukropec et al., 2010).

\subsection{Limitations of the Study}

There are limitations in this study. First, bias may exist for published data; non-English except Persian language studies were not included. Second, range time research was between 2000 and 2016.

\section{Conclusions}

Systematic review and Meta-analysis showed that p,p'-DDE in the serum and adipose tissue increased the risk of T2D significantly $(\mathrm{P}<0.001)$. Results of this study, supports the role of $\mathrm{p}, \mathrm{p}$ '-DDE as an environmental risk factor for T2D.

\section{Acknowledgments}

Environmental Health Research Center, School of Public Health, Semnan University of Medical Sciences, was the financer of this review research (Code: A-10-268-1).

\section{Competing Interests Statement}

The authors declare that there is no conflict of interests regarding the publication of this paper.

\section{References}

Agency for Toxic Substances and Disease Registry (ATSDR). (1994). Toxicological Profile for 4,4-DDT, 4,4-DDE, and 4,4-DDD. Public Health Service, U.S. Department of Health and Human Services, Atlanta, GA.

Airaksinen, R., Rantakokko, P., Eriksson, J. G., Blomstedt, P., Kajantie, E., \& Kiviranta, H. (2011). Association between type 2 diabetes and exposure to persistent organic pollutants. Diabetes Care, 34, 1972-1979. http://dx.doi.org/10.2337/dc10-2303

Arrebola, J. P., Fernández, M. F., Olea, N., Ramos, R., \& Martin-Olmedo, P. (2013). Human exposure to p,p' -dichlorodiphenyldichloroethylene (p,p' -DDE) in urban and semi-rural areas in southeast Spain: A gender perspective. Science of the Total Environment, 458, 209-216. http://dx.doi.org/10.1016/j.scitotenv. 2013.04.001

Arrebola, J. P., Pumarega, J., Gasull, M., Fernandez, M. F., Martin-Olmedo, P., Molina-Molina, J. M., ... Olea, N. (2013). Adipose tissue concentrations of persistent organic pollutants and prevalence of type 2 diabetes in adults from Southern Spain. Environmental research, 122, 31-37. http://dx.doi.org/10.1016/j.envres. 2012.12.001

Azandjeme, C. S., Delisle, H., Fayomi, B., Ayotte, P., Djrolo, F., Houinato, D., \& Bouchard, M. (2014). High serum organochlorine pesticide concentrations in diabetics of a cotton producing area of the Benin Republic (West Africa). Environment international, 69, 1-8. http://dx.doi.org/10.1016/j.envint.2014.04.002

Bilrha, H., Roy, R., Moreau, B., Belles-Isles, M., Dewailly, É., \& Ayotte, P. (2003). In vitro activation of cord blood mononuclear cells and cytokine production in a remote coastal population exposed to organochlorines and methyl mercury. Environmental Health Perspectives, 111, 1952. http://dx.doi.org/10.1289/ehp.6433

Codru, N., Schymura, M. J., Negoita, S., Environment, A. T. F. O. T., Rej, R., \& Carpenter, D. O. (2007). 
Diabetes in relation to serum levels of polychlorinated biphenyls and chlorinated pesticides in adult Native Americans. Environmental health perspectives, 1442-1447. http://dx.doi.org/10.1289/ehp.10315

Cornelis, M. C., Zaitlen, N., Hu, F. B., Kraft, P., \& Price, A. L. (2015). Genetic and environmental components of family history in type 2 diabetes. Human genetics, 134, 259-267. http://dx.doi.org/10.1007/s00439-014 $-1519-0$

Cox, S., Niskar, A. S., Narayan, K. V., \& Marcus, M. (2007). Prevalence of self-reported diabetes and exposure to organochlorine pesticides among Mexican Americans: Hispanic health and nutrition examination survey, 1982-1984. Environmental health perspectives, 1747-1752. http://dx.doi.org/10.1289/ehp.10258

Daniel, V., Huber, W., Bauer, K., Suesal, C., Conradt, C., \& Opelz, G. (2002). Associations of dichlorodiphenyltrichloroethane (DDT) 4.4 and dichlorodiphenyldichloroethylene (DDE) 4.4 blood levels with plasma IL-4. Archives of Environmental Health: An International Journal, 57, 541-547. http://dx.doi.org/10.1080/00039890209602086

Das, U. N. (2010). Obesity: Genes, brain, gut, and environment. Nutrition, 26, 459-473. http://dx.doi.org/10.1016/j.nut.2009.09.020

DeFronzo, R. A., Ferrannini, E., Zimmet, P., \& Alberti, G. (2015). International textbook of diabetes mellitus. John Wiley \& Sons,

Dorea, J., Cruz-Granja, A., Lacayo-Romero, M., \& Cuadra-Leal, J. (2001). Perinatal metabolism of dichlorodiphenyldichloroethylene in Nicaraguan mothers. Environmental research, 86, 229-237. http://dx.doi.org/10.1006/enrs.2001.4277

Durand, C. P., Promotion, T. U. O. T. S. O. P. H. H., \& Management, B. S. (2008). A Systematic Review and Meta-analysis of Diabetes Disease Management Programs. University of Texas School of Public Health.

Egger, M., Davey-Smith, G., \& Altman, D. (2008). Systematic Reviews in Health Care: Meta-Analysis in Context. Wiley.

Eichler, E. E., Flint, J., Gibson, G., Kong, A., Leal, S. M., Moore, J. H., \& Nadeau, J. H. (2010). Missing heritability and strategies for finding the underlying causes of complex disease. Nature Reviews Genetics, 11, 446-450. http://dx.doi.org/10.1038/nrg2809

Federation, I. D. (2011). IDF diabetes atlas. International Diabetes Federation, Executive Office.

Fernández-González, R., Yebra-Pimentel, I., Martínez-Carballo, E., \& Simal-Gándara, J. (2015). A Critical Review about Human Exposure to Polychlorinated Dibenzo-p-Dioxins (PCDDs), Polychlorinated Dibenzofurans (PCDFs) and Polychlorinated Biphenyls (PCBs) through Foods. Critical reviews in food science and nutrition, 55, 1590-1617. http://dx.doi.org/10.1080/10408398.2012.710279

Gasull, M., Pumarega, J., Téllez-Plaza, M., Castell, C., Tresserras, R., Lee, D. H., \& Porta, M. (2012). Blood concentrations of persistent organic pollutants and prediabetes and diabetes in the general population of Catalonia. Environmental science \& technology, 46, 7799-7810. http://dx.doi.org/10.1021/es300712g

Gray, S. L., Shaw, A. C., Gagne, A. X., \& Chan, H. M. (2013). Chronic exposure to PCBs (Aroclor 1254) exacerbates obesity-induced insulin resistance and hyperinsulinemia in mice. Journal of Toxicology and Environmental Health, 76, 701-715. http://dx.doi.org/10.1080/15287394.2013.796503

Group, L. A. R. (2013). Cardiovascular effects of intensive lifestyle intervention in type 2 diabetes. The New England Journal of Medicine, 369, 145. http://dx.doi.org/10.1056/NEJMoa1212914

Hectors, T., Vanparys, C., Van Der Ven, K., Martens, G., Jorens, P., Van Gaal, L., ... Blust, R. (2011). Environmental pollutants and type 2 diabetes: A review of mechanisms that can disrupt beta cell function. Diabetologia, 54, 1273-1290. http://dx.doi.org/10.1007/s00125-011-2109-5

Higgins, J. P., \& Green, S. (2008). Cochrane handbook for systematic reviews of interventions. Wiley Online Library, 5. http://dx.doi.org/10.1002/9780470712184

Hu, F. B. (2011). Globalization of Diabetes The role of diet, lifestyle, and genes. Diabetes care, 34, 1249-1257. http://dx.doi.org/10.2337/dc11-0442

Kahn, S. (2003). The relative contributions of insulin resistance and beta-cell dysfunction to the pathophysiology of type 2 diabetes. Diabetologia, 46, 3-19.

Katzmarzyk, P. T. (2008). Obesity and physical activity among Aboriginal Canadians. Obesity, 16, 184-190. http://dx.doi.org/10.1038/oby.2007.51 
Langer, P., Kočan, A., Tajtaková, M., Petrík, J., Chovancová, J., Drobná, B., .. Kšinantová, L. (2007). Fish from industrially polluted freshwater as the main source of organochlorinated pollutants and increased frequency of thyroid disorders and dysglycemia. Chemosphere, 67, S379-S385. http://dx.doi.org/10.1016/j. chemosphere.2006.05.132

Lee, D.-H., Lee, I.-K., Song, K., Steffes, M., Toscano, W., Baker, B. A., \& Jacobs, D. R. (2006). A strong dose-response relation between serum concentrations of persistent organic pollutants and diabetes results from the National Health and Examination Survey 1999-2002. Diabetes Care, 29, 1638-1644. http://dx.doi.org/10.2337/dc06-0543

Marchand, A., Tomkiewicz, C., Marchandeau, J.-P., Boitier, E., Barouki, R., \& Garlatti, M. (2005). 2, 3, 7, 8-Tetrachlorodibenzo-p-dioxin induces insulin-like growth factor binding protein-1 gene expression and counteracts the negative effect of insulin. Molecular pharmacology, 67, 444-452. http://dx.doi.org/10. 1124/mol.104.004010

Mostafalou, S. (2016). Persistent Organic Pollutants and Concern over the Link with Insulin Resistance Related Metabolic Diseases.

Patel, C. J., Bhattacharya, J., \& Butte, A. J. (2010). An environment-wide association study (EWAS) on type 2 diabetes mellitus. PloS one, 5, e10746. http://dx.doi.org/10.1371/journal.pone.0010746

Philibert, A., Schwartz, H., \& Mergler, D. (2009). An exploratory study of diabetes in a First Nation community with respect to serum concentrations of p,p'-DDE and PCBs and fish consumption. International Journal of Environmental Research and Public Health, 6, 3179-3189. http://dx.doi.org/10.3390/ijerph6123179

Rasier, G., Toppari, J., Parent, A.-S., \& Bourguignon, J.-P. (2006). Female sexual maturation and reproduction after prepubertal exposure to estrogens and endocrine disrupting chemicals: A review of rodent and human data. Molecular and cellular endocrinology, 254, 187-201. http://dx.doi.org/10.1016/j.mce.2006.04.002

Research, J. H. L. B. M. G. S. S. W. S., University, J. C. V. C., \& Arlington, V. P. U. T. (2008). Systematic Reviews and Meta-Analysis. Oxford University Press, USA.

Rignell-Hydbom, A., Lidfeldt, J., Kiviranta, H., Rantakokko, P., Samsioe, G., Agardh, C.-D., \& Rylander, L. (2009). Exposure to p, p'-DDE: A risk factor for type 2 diabetes. PloS one, 4, e7503. http://dx.doi.org/10. 1371/journal.pone.0007503

Rothstein, H. R., Sutton, A. J., \& Borenstein, M. (2006). Publication Bias in Meta-Analysis: Prevention, Assessment and Adjustments. Wiley.

Silverstone, A. E., Rosenbaum, P. F., Weinstock, R. S., Bartell, S. M., Foushee, H. R., Shelton, C., \& Pavuk, M. (2012). Polychlorinated biphenyl (PCB) exposure and diabetes: Results from the Anniston Community Health Survey. Environmental health perspectives, 120. http://dx.doi.org/10.1289/ehp.1104247

Sodium Bicarbonate hazards. Nutrition and Health. Retrieved August 20, 2011, from http://www.behsite.ir/content/articles/314/1875

Song, Y., Chou, E. L., Baecker, A., You, N. C. Y., Song, Y., Sun, Q., \& Liu, S. (2015). Endocrine-disrupting chemicals, risk of type 2 diabetes, and diabetes-related metabolic traits: A systematic review and meta-analysis. Journal of diabetes. http://dx.doi.org/10.1111/1753-0407.12325

Sunyer, J., Torrent, M., Muñoz-Ortiz, L., Ribas-Fitó, N., Carrizo, D., Grimalt, J., ... Cullinan, P. (2005). Prenatal dichlorodiphenyldichloroethylene (DDE) and asthma in children. Environmental health perspectives, 1787-1790. http://dx.doi.org/10.1289/ehp.8127

Surveillance for dental caries. (2005). CDC, dental sealants, tooth retention, edentulism, and enamel fluorosis: United States, 1988-1994 and 1999-2002. Department of Health and Human Services, Centers for Disease Control and Prevention, 54.

Taylor, K. W., Novak, R. F., Anderson, H. A., Birnbaum, L. S., Blystone, C., DeVito, M., ... Rylander, L. (2013). Evaluation of the association between persistent organic pollutants (POPs) and diabetes in epidemiological studies: A national toxicology program workshop review. Environmental health perspectives, 121, 774-783. http://dx.doi.org/10.1289/ehp.1205502

Thayer, K. A., Heindel, J. J., Bucher, J. R., \& Gallo, M. A. (2012). Role of environmental chemicals in diabetes and obesity: A National Toxicology Program workshop review. Environ Health Perspect, 120, 779-789. http://dx.doi.org/10.1289/ehp.1104597

Tonack, S., Kind, K., Thompson, J. G., Wobus, A. M., Fischer, B., \& Santos, A. N. (2007). Dioxin affects glucose 
transport via the arylhydrocarbon receptor signal cascade in pluripotent embryonic carcinoma cells. Endocrinology, 148, 5902-5912. http://dx.doi.org/10.1210/en.2007-0254

Turusov, V., Rakitsky, V., \& Tomatis, L. (2002). Dichlorodiphenyltrichloroethane (DDT): Ubiquity, persistence, and risks. Environmental health perspectives, 110, 125. http://dx.doi.org/10.1289/ehp.02110125

Turyk, M., Anderson, H., Knobeloch, L., Imm, P., \& Persky, V. (2009). Organochlorine exposure and incidence of diabetes in a cohort of Great Lakes sport fish consumers. Environ Health Perspect, 117, 1076-82. http://dx.doi.org/10.1289/ehp.0800281

Turyk, M., Fantuzzi, G., Persky, V., Freels, S., Lambertino, A., Pini, M., ... Anderson, H. A. (2015). Persistent organic pollutants and biomarkers of diabetes risk in a cohort of Great Lakes sport caught fish consumers. Environmental research, 140, 335-344. http://dx.doi.org/10.1016/j.envres.2015.03.037

U.S. Environmental Protection Agency. Deposition of Air Pollutants to the Great Waters. EPA-453/R-93-055. First Report to Congress. Office of Air Quality Planning and Standards, Research Triangle Park, NC. 1994.

Ukropec, J., Radikova, Z., Huckova, M., Koska, J., Kocan, A., Sebokova, E., ... Labudova, V. (2010). High prevalence of prediabetes and diabetes in a population exposed to high levels of an organochlorine cocktail. Diabetologia, 53, 899-906. http://dx.doi.org/10.1007/s00125-010-1683-2

Van Larebeke, N., Sioen, I., Den Hond, E., Nelen, V., Van de Mieroop, E., Nawrot, T., ... Baeyens, W. (2015). Internal exposure to organochlorine pollutants and cadmium and self-reported health status: A prospective study. International Journal of Hygiene and Environmental Health, 218, 232-245. http://dx.doi.org/10.1016 /j.ijheh.2014.11.002

Von Elm, E., Altman, D. G., Egger, M., Pocock, S. J., Gøtzsche, P. C., Vandenbroucke, J. P., \& Initiative, S. (2007). The Strengthening the Reporting of Observational Studies in Epidemiology (STROBE) statement: Guidelines for reporting observational studies. Preventive medicine, 45, 247-251. http://dx.doi.org/10.1016/ j.ypmed.2007.08.012

Wallin, A., Di Giuseppe, D., Orsini, N., Åkesson, A., Forouhi, N. G., \& Wolk, A. (2015). Fish consumption and frying of fish in relation to type 2 diabetes incidence: A prospective cohort study of Swedish men. European Journal of Nutrition, 1-10. http://dx.doi.org/10.1007/s00394-015-1132-6

Wang, S.-L., Tsai, P.-C., Yang, C.-Y., \& Guo, Y. L. (2008). Increased Risk of Diabetes and Polychlorinated Biphenyls and Dioxins a 24-year follow-up study of the Yucheng cohort. Diabetes Care, 31, 1574-1579. http://dx.doi.org/10.2337/dc07-2449

Wendo, C. (2004). Uganda considers DDT to protect homes from malaria. The Lancet, 363, 1376. http://dx.doi.org/10.1016/s0140-6736(04)16095-9

Wild, S., Roglic, G., Green, A., Sicree, R., \& King, H. (2004). Global prevalence of diabetes estimates for the year 2000 and projections for 2030. Diabetes care, 27, 1047-1053. http://dx.doi.org/10.2337/diacare.27. 5.1047

World Health Organization (WHO). (2013). Diabetes.

World Health Organization. (2010). Persistent Organic Pollutants: Impact on Child Health. Geneva: World Health Organization. Retrieved August 9, 2013, from http://www.who.int/ceh/publications/persistent organic_pollutant/en/index.html

Wu, H., Bertrand, K. A., Choi, A. L., Hu, F. B., Laden, F., Grandjean, P., \& Sun, Q. (2012). Persistent organic pollutants and type 2 diabetes: A prospective analysis in the nurses' health study and meta-analysis. Environmental health perspectives, 121, 153-161. http://dx.doi.org/10.1289/ehp.1205248

Yu, Y. X., Zhang, S. H., Huang, N. B., Li, J. L., Pang, Y. P., Zhang, X. Y., ... Xu, Z. G. (2012). Polybrominated diphenyl ethers and polychlorinated biphenyls in freshwater fish from Taihu Lake, China: Their levels and the factors that influence biomagnification. Environmental Toxicology and Chemistry, 31, 542-549. http://dx.doi.org/10.1002/etc. 1722

\section{Copyrights}

Copyright for this article is retained by the author(s), with first publication rights granted to the journal.

This is an open-access article distributed under the terms and conditions of the Creative Commons Attribution license (http://creativecommons.org/licenses/by/3.0/). 